\title{
Consumption Patterns for Ready to Eat Foods Items in Phagwara District of Punjab (India)
}

\author{
Ashish Raina, Dhiraj Pathak, Varinder Singh Rana, Gaurav Bathla
}

\begin{abstract}
The purpose of this study was to examine consumption patterns for ready to eat foods in Phagwara district of Punjab. The study also focused to read food related lifestyle and behaviour of people towards ready to eat food products available in the markets. Defined objectives of the study were fulfilled by collecting primary data in the form of questionnaires, interviews and observations. Primary data was collected from 184 respondents with the help of 18 close ended questions. Data was subjected to statistical tools to gauze the use of ready to eat foods in specified locations. The study concluded that a major segment of ready to eat food products consumers buy these products at discounts from the super markets in the area and another rapidly consuming segment of ready to eat food products prefer these products as a part of convenience in the lifestyle. Further the results from the descriptive statistics showed the rating by the previous consumers is the most influencing factor in deciding the type and brand of ready to use food product. In order to check the impact of gender on the decision of choosing ready to eat products, data filled by the respondents was referred to independent sample $t$ test. Results from the t test described a difference in the gender while using ratings in consumption patterns. The results of the study can be used to develop a proper ready to eat food product market in rural and remote locations of the targeted area.
\end{abstract}

Keywords: Ready to eat food, Phagwara, food lifestyle and food patterns.

\section{INTRODUCTION}

Modern age is an age of technology. Life has already been transformed up to a level of ease where efforts by mankind are getting reduced with every new advancement in day today activities. Whether it is the field of entertainment or the area where basic human needs are to be fulfilled, technology is overtaking human efforts. We humans have already been observed getting slave to technology at every now and then. Considering various stages in life starting from the age where a child has just started to hold himself as an individual to the grey haired phase of life, technology has already become a need rather than convenience to a limit.

Talking about the kitchen which were always considered as female domain in most of the households in India, technological advancements are reducing the effort levels to a least possible point. Technology has started altering the human efforts in cooking right from to development in the

\footnotetext{
Revised Manuscript Received on July 18, 2019.

Ashish Raina, Research Scholar, Faculty of Hospitality, GNA University, Phagwara (Punjab)

Dhiraj Pathak Research Scholar \& Assistant Professor, GNA University, Phagwara (Punjab)

Varinder Singh Rana3Dean - Faculty of Hospitality, GNA University, Phagwara (Punjab)

Gaurav Bathla Research Scholar \& Assistant Professor, Faculty of Hospitality, GNA University, Phagwara (Punjab)
}

field of electronics to complex machines. Invention of roti makers to the automatic vegetable peelers, technology in the kitchen is ruling every other simpler task. Many of the time taking processes can be completed within fraction of time with least involvement of human efforts. It will not be strange to say that cake now a days can be baked just by adding specified ingredients in high tech machines and clicking few buttons. Talking about many such advancements in the field of cooking, it becomes must to consider ready to eat food products which are dominating modern households/ lifestyles now a days. Catering guests at homes is no more a tedious task for anyone cooking in the kitchens. This has made possible by the introduction of ready to eat food products in the society. Talking specifically about frozen food, no one will feel astonished if I pin point the shoppers bringing ready to eat pranthas from the supermarkets these days.

India has already moderated itself into one of the largest food producers in the world after China. The global food processing industry is estimated about 3.6 trillion US dollars which accounts three fourth of total food sales in the world. In year 2007, food industry in India was valued to 200 Billion US Dollars. Food processing sector in India deals in fruits, vegetables, processing of various grains \& nuts, dairy products, sea foods as well as all alcoholic and nonalcoholic beverages. Confectionary products, soya products, mineral water and many Indian food dishes from all parts of the country are processed and already made available to the consumers in the form of processed foods which are also termed as convenience foods or ready to eat foods. In a research paper, Shipra Singh in year 2011 concluded India emerging as food basket to the world.

According to NSSCO (National sample survey organisation) the demands of customers are changing gradually from cereals to high nutrients foods such as fruits $\&$ vegetables.

\section{LITERATURE REVIEW}

Venkateshwaralu et al. (1987) mentioned in their study about buying behavior of customers towards biscuits has concluded that customers prefer to buy packed biscuits over unpacked biscuits. Further it was been found that 76 percent of respondents are buying biscuits at least once in a week and the children majorly influence the decision about the choice of brand. 

(INDIA)

Rees (1992) surveyed the respondents and concluded that flavor, appearance and advertisement are the major factors influencing choice of the customers. In his paper it has been observed that technological advancements like introduction of microwaves, changing work culture in women $\&$ single people staying away from homes, developments of supermarkets and awareness among customers towards safety and food hygiene are some of major factors influencing the use of packed and convenience foods.

Hans et al. (1996) admitted that factors like variety, motivations, curiosity and pricing influence the buying behavior and brand loyalty of ready to eat food customers.

Srinivasan (2000) researched that level of education also influences the buying behavior in consumers. Srinivasan also reported that high income customers prefer fresh fruits and vegetables and convenience food as it is ready to use. The paper also highlighted that an increase more than five percent in prices may lead to discontinuation of ready to eat food products.

Brown et al. (2000) highlighted fast food and ready to eat food consumption behavior opined that there is an apparent need of nutritional education in young generation. His research concluded that the food habits of young generations direct to fast food whereas this generations is well aware of the healthy eating practices.

White (2001) studied motivating factors for buyers of fast food in US and examined that 56.6 percent of the total respondents purchase convenience food locally and 39 percent respondents purchase convenience food online as if it is not available in localities. Further, price was considered as a relatively less motivating factor in buying fast food.

Foret (2006) analyzed the preference of the customers when buying beverages. The data collected from customers between years 1993 to 2004 concluded that customers prefer to buy beverages from leading outlets which further indicate customer's awareness towards healthy eating.

Renuka (2008) made an attempt to analyze buying behavior towards ready to eat foods claims that $94 \%$ of the total sample size (200 respondents) consume such products in day today lifestyles. Taste and health consciousness were concluded as main factor influencing the buying behavior. It was further concluded that use of ready to eat products was higher with high income customers and brand loyalty is higher in case of younger generation while buying such
products.Banumathy and Hemameena (2015) mentioned about companies that manufactures soft drinks must produce high quality soft drinks to compete with the taste of soft drinks of multinational companies (MNC). Study also exposed that there is no association between age, education, occupation and choice of brands.

\section{OBJECTIVES OF THE STUDY}

1. To review consumption pattern for ready to eat foods items in Phagwara district of Punjab.

2. To find out the most effective factor which influences the decision of choosing ready to eat foods in today's generation.

\section{STUDY AREA}

According to the Indian census 2011, Phagwara is a Municipal council city in District Kapurthala, Punjab. The city has a population of 97,864 with 51,386 males and 46,478 females divided into 27 wards. The Literacy rate of Phagwara is $86.82 \%$ in total 20,719 houses with water and sewerage connections. Out of total population $35.7 \%$ are working class doing business, job, service or cultivation or laborious tasks . Only $8.59 \%$ of the total working class is engaged in marginal work(laborious jobs).

\section{METHODOLOGY AND SAMPLING}

Random sampling techniques are used to collect primary data from the respondents. Data is collected in the form of questionnaires filled by respondents from different areas in Phagwara and its adjoining localities. A total of 250 respondents have been approached through internet and about 35 respondents have filled questionnaires in hard copies. Further, based on the type of target areas data is also be collected by interviewing respondents who were not able to attempt e-questionnaires and hard copies. High literacy rate helped to get a very good response rate was from the research areas. Out of 250 approached respondents, 184 responses were recorded adequately which expresses $73.6 \%$ of response rate from the area.

Secondary data is also used referred from government of India's publications, census reports, previous researches in the area, internet sources etc.

\section{FINDINGS \& RESULTS}

Table-1 Respondent's Profile

\begin{tabular}{|l|c|c|c|}
\hline Characteristics & $\begin{array}{l}\text { Convenience food } \\
\text { consumers }\end{array}$ & $\begin{array}{l}\text { Percentage from Total } \\
\text { respondents }\end{array}$ & Total respondents \\
\hline Gender & 101 & 54.9 & 184 \\
\hline Male & 83 & 45.1 & 184 \\
\hline Female & 95 & 51.9 & 184 \\
\hline Age in years & 64 & 35 & 184 \\
\hline $15-25$ & 20 & 10.9 & 184 \\
\hline $26-35$ & \multicolumn{5}{|l|}{} \\
\hline $36-45$ &
\end{tabular}




\begin{tabular}{|c|c|c|c|}
\hline Above 45 & 05 & 02.2 & 184 \\
\hline \multicolumn{4}{|l|}{ Educational qualifications } \\
\hline Post Graduate & 82 & 44.6 & 184 \\
\hline Graduate & 89 & 48.4 & 184 \\
\hline School Going & 09 & 04.9 & 184 \\
\hline Others(uneducated) & 04 & 02.2 & 184 \\
\hline \multicolumn{4}{|l|}{ Profession } \\
\hline Students & 78 & 42.6 & 184 \\
\hline Working in private sector & 73 & 39.9 & 184 \\
\hline Business owners & 13 & 07.1 & 184 \\
\hline Government officials & 13 & 07.1 & 184 \\
\hline Home makers & 07 & 03.3 & 184 \\
\hline \multicolumn{4}{|l|}{ Marital Status } \\
\hline Married & 130 & 70.7 & 184 \\
\hline Unmarried & 52 & 28.2 & 184 \\
\hline Other (single parent) & 2 & 1.1 & 184 \\
\hline \multicolumn{4}{|l|}{ Residential Location } \\
\hline Urban & 87 & 48.9 & 184 \\
\hline Suburban & 43 & 20.8 & 184 \\
\hline Rural & 54 & 30.3 & 184 \\
\hline
\end{tabular}

Table-1 Respondent's Profile

\begin{tabular}{|c|c|c|c|c|c|}
\hline \multicolumn{7}{|c|}{ Descriptive Statistics } \\
\hline & $\mathrm{N}$ & Minimum & Maximum & Mean & Std. Deviation \\
\hline Value RTEF & 184 & 1 & 5 & 3.60 & 0.998 \\
\hline Cost Effectiveness & 184 & 1 & 5 & 3.57 & 0.961 \\
\hline Brand Reliability & 184 & 1 & 5 & 3.88 & 0.850 \\
\hline Packaging & 184 & 1 & 5 & 3.74 & 0.995 \\
\hline Hygiene and Safety & 184 & 1 & 5 & 3.95 & 0.979 \\
\hline Availability & 184 & 1 & 5 & 3.59 & 0.998 \\
\hline Rating Taste of RTEF & 184 & 2 & 5 & 4.42 & 0.720 \\
\hline Valid N (listwise) & 184 & & & & \\
\hline
\end{tabular}

\section{Table-1.1}

Results of the descriptive statistics applied to the data in IBM SPSS 25 are shown in table.1.

It has been observed that out of all seven factors respondents have emphasised the rating given by the previous consumers of the product as a prime factor in choosing ready to use food products. According to the mean values shown in the table-1, rating of the products is the prime factor to buy ready to eat food products followed by hygiene and safety, brand reliability, packaging, value for money, availability and in last competitive pricing.

\section{Group Statistics}

\begin{tabular}{|c|c|c|c|c|c|}
\hline \multicolumn{2}{|c|}{ Gender. } & $\mathrm{N}$ & Mean & Std. Deviation & Std. Error Mean \\
\hline \multirow{3}{*}{ Value RTEF } & Female & 84 & 3.67 & 0.883 & 0.096 \\
\cline { 2 - 6 } & Male & 100 & 3.54 & 1.086 & 0.109 \\
\hline \multirow{2}{*}{ Bost Effectiveness } & Female & 84 & 3.65 & 0.925 & 0.101 \\
\cline { 2 - 6 } & Male & 100 & 3.50 & 0.990 & 0.099 \\
\hline \multirow{2}{*}{ Packaging } & Female & 84 & 3.90 & 0.801 & 0.087 \\
\cline { 2 - 6 } & Male & 100 & 3.85 & 0.892 & 0.089 \\
\hline \multirow{2}{*}{ Hygiene and Safety } & Female & 84 & 3.82 & 0.971 & 0.106 \\
\cline { 2 - 6 } & Male & 100 & 3.68 & 1.014 & 0.101 \\
\cline { 2 - 6 } & Female & 84 & 3.85 & 1.058 & 0.115 \\
\hline Availability & Male & 100 & 4.03 & 0.904 & 0.090 \\
\cline { 2 - 6 } & Female & 84 & 3.67 & 0.923 & 0.101 \\
\hline Rating Taste of RTEF & Male & 100 & 3.53 & 1.058 & 0.106 \\
\cline { 2 - 6 } & Female & 84 & 4.56 & 0.588 & 0.064 \\
\hline
\end{tabular}

Table -2 


\begin{tabular}{|c|c|c|c|c|c|c|c|c|c|c|}
\hline \multicolumn{11}{|c|}{ Independent Samples Test } \\
\hline & & \multicolumn{2}{|c|}{$\begin{array}{l}\text { Levene's Test } \\
\text { for Equality of } \\
\text { Variances }\end{array}$} & \multicolumn{7}{|c|}{ t-test for Equality of Means } \\
\hline & & \multirow[b]{2}{*}{$\mathrm{F}$} & \multirow[b]{2}{*}{ Sig. } & \multirow[b]{2}{*}{$\mathrm{t}$} & \multirow[b]{2}{*}{ df } & \multirow{2}{*}{$\begin{array}{l}\text { Sig. (2- } \\
\text { tailed) }\end{array}$} & \multirow{2}{*}{$\begin{array}{c}\text { Mean } \\
\text { Difference }\end{array}$} & \multirow{2}{*}{$\begin{array}{l}\text { Std. Error } \\
\text { Difference }\end{array}$} & \multicolumn{2}{|c|}{$\begin{array}{l}\text { 95\% Confidence } \\
\text { Interval of the } \\
\text { Difference }\end{array}$} \\
\hline & & & & & & & & & Lower & Upper \\
\hline \multirow[t]{2}{*}{ Value RTEF } & $\begin{array}{l}\text { Equal variances } \\
\text { assumed }\end{array}$ & 2.975 & 0.086 & 0.857 & 182 & 0.393 & 0.127 & 0.148 & -0.165 & 0.418 \\
\hline & $\begin{array}{l}\text { Equal variances } \\
\text { not assumed }\end{array}$ & & & 0.872 & 181.813 & 0.384 & 0.127 & 0.145 & -0.160 & 0.413 \\
\hline \multirow[t]{2}{*}{$\begin{array}{l}\text { Cost } \\
\text { Effectiveness }\end{array}$} & $\begin{array}{l}\text { Equal variances } \\
\text { assumed }\end{array}$ & 0.152 & 0.697 & 1.088 & 182 & 0.278 & 0.155 & 0.142 & -0.126 & 0.435 \\
\hline & $\begin{array}{l}\text { Equal variances } \\
\text { not assumed }\end{array}$ & & & 1.095 & 179.919 & 0.275 & 0.155 & 0.141 & -0.124 & 0.434 \\
\hline \multirow[t]{2}{*}{\begin{tabular}{|l} 
Brand \\
Reliability
\end{tabular}} & $\begin{array}{l}\text { Equal variances } \\
\text { assumed }\end{array}$ & 0.479 & 0.490 & 0.434 & 182 & 0.664 & 0.055 & 0.126 & -0.194 & 0.303 \\
\hline & $\begin{array}{l}\text { Equal variances } \\
\text { not assumed }\end{array}$ & & & 0.439 & 181.169 & 0.661 & 0.055 & 0.125 & -0.192 & 0.301 \\
\hline \multirow[t]{2}{*}{ Packaging } & $\begin{array}{l}\text { Equal variances } \\
\text { assumed }\end{array}$ & 0.505 & 0.478 & 0.961 & 182 & 0.338 & 0.141 & 0.147 & -0.149 & 0.432 \\
\hline & $\begin{array}{l}\text { Equal variances } \\
\text { not assumed }\end{array}$ & & & 0.964 & 178.845 & 0.336 & 0.141 & 0.147 & -0.148 & 0.431 \\
\hline \multirow[t]{2}{*}{$\begin{array}{l}\text { Hygiene and } \\
\text { Safety }\end{array}$} & $\begin{array}{l}\text { Equal variances } \\
\text { assumed }\end{array}$ & 6.591 & 0.011 & -1.277 & 182 & 0.203 & -0.185 & 0.145 & -0.470 & 0.101 \\
\hline & \begin{tabular}{|l} 
Equal variances \\
not assumed \\
\end{tabular} & & & -1.260 & 164.196 & 0.210 & -0.185 & 0.147 & -0.474 & 0.105 \\
\hline \multirow[t]{2}{*}{ Availability } & $\begin{array}{l}\text { Equal variances } \\
\text { assumed }\end{array}$ & 1.571 & 0.212 & 0.924 & 182 & 0.356 & 0.137 & 0.148 & -0.155 & 0.428 \\
\hline & $\begin{array}{l}\text { Equal variances } \\
\text { not assumed }\end{array}$ & & & 0.936 & 181.737 & 0.351 & 0.137 & 0.146 & -0.152 & 0.425 \\
\hline \multirow[t]{2}{*}{$\begin{array}{l}\text { Rating Taste of } \\
\text { RTEF }\end{array}$} & $\begin{array}{l}\text { Equal variances } \\
\text { assumed }\end{array}$ & 7.430 & 0.007 & 2.370 & 182 & 0.019 & 0.250 & 0.105 & 0.042 & 0.457 \\
\hline & $\begin{array}{l}\text { Equal variances } \\
\text { not assumed }\end{array}$ & & & 2.433 & 178.979 & 0.016 & 0.250 & 0.103 & 0.047 & 0.452 \\
\hline
\end{tabular}

\section{Table-3}

\section{CONCLUSION}

Results obtained by the application of independent sample $t$ test shows that there is no significant difference in the scores for males and females ganders for all the factors other than ratings given by the previous consumers of the ready to eat food products. It can be concluded that all six factors considered in the study which effect the buying behaviour for ready to eat foods serve same to male and female genders, where as there is a difference in the between in choice based on gender for the population considering ratings given by the previous users of ready to eat food products.

\section{REFERENCES}

1. Banumathy, S.and Hemameena, M., (2015), Analysis of brand preference of soft drinks in global environment, Indian Journal of Marketing, Vol.36, Issue 6, 12-16

2. Brown, K., Mcllveen, H., and Strugnell, C, (2000), Nutritional awareness and food preferences of young consumers in Northern Ireland, Nutrition and food Science,Vol.30, Issue 4, 230-235.

3. Foret (2006),Behaviour and decision making of Czech consumers when buying beverages, Agricultural Economy, Issue $7,341-346$.
4. Hans, C.M. and Trijp, P,(1996), Why switch Product category level exploitation for true variety seeking behaviour, American Journal of Marketing Research,32(3):105-116.

5. http://www.census2011.co.in/data/town/800158-phagwarapunjab.html

6. Rees, A. M, (1992), 'Factors influencing consumer choice', Journal of the Society of Dairy Technology, Vol.45, Issue 4, 112-116.

7. Renuka Hirekenchanagoudar (2008), Consumer behaviour towards ready -to -eat food products, MBA Thesis, University of Agricultural Sciences, Dharwad, 3-87.

8. Srinivasan, N. and Elangovan, D., (2000), Consumer perception towards processed fruits and vegetable products, Indian Journal of Marketing, 30(11):22-25.

9. Venkateshwaralu, Kishore Kumar. M, Rajanath. K, (1987) 'A Behavioural analysis on consumer decision making', Indian Journal of Marketing, Issue 4, 3-9.

10. White, G.K. and Manning, B.J, (2001), Convenience, price, product: motivators for online specialty food consumers, Journal of Food Products Marketing, 7(1): 53-65. 